\title{
Analysis of main problems and challenges in the functioning of voluntary fire brigades in the Mazovian Voivodeship
}

\section{Paulina Żurawicka, Monika Kierzkowska, Dariusz Piwowarczyk}

\begin{abstract}
The article presents results of an analysis of the main needs, problems and challenges in the functioning of volunteer fire brigades in the Mazovian Voivodeship. A survey addressed to the Mazovian OSP units was conducted in order to identify them. The analysis determined the needs of voluntary fire brigades in terms of improving their equipment, increasing the efficiency of their members to carry out rescue actions and collecting information about the readiness of the units to carry out rescue operations. The submitted answers made it possible to identify the forms of support preferred by the OSP units.

This analysis is also supplemented with basic information on the National Firefighting and Rescue System and an analysis of the regulations constituting the legal grounds for functioning and financing of the voluntary fire brigades, including in particular the Act on Fire Protection of August 24, 1991, and the Associations Act of April 7, 1989.
\end{abstract}

Key words: volunteer fire brigades, National Firefighting and Rescue System, the Mazovian Voivodeship

\section{Introduction}

Voluntary fire brigades (OSP) play an important role in the system of national internal security, supporting rescue actions of state services, especially during rescue operations in rural areas. The units consist of trained volunteers, who often match professional firefighters in terms of their effectiveness and skills. There are about two thousand OSP units in the Mazovian Voivodeship [www.mazovia.pl 07.02.2020]. What they need the most to carry out effective rescue actions is specialised equipment. Shortages in this field are a big problem, which is caused by a limited financial capacity of municipalities - the authorities, who are obliged by the legislator to bear costs of equipping, maintaining, training and ensuring readiness of volunteer fire brigades [Act of 24 August 1991 on Fire Protection (art. 32 of the Act on Fire Protection)]. The paper attempts to determine what kind of problems and challenges the OSP units operating in the Mazovian Voivodeship are encountering, as well as what kind of support these units expect to receive from the authorities.

The Mazovian Voivodeship self-government has been financially supporting the voluntary fire brigades for many years in order to ensure public safety in the region. Funds 
received by them from the regional budget pay for the renovation of fire stations and purchase of fire engines, professional equipment and protective clothing. These funds allow for conducting efficient operations in the field of protecting the health, life and property of the residents while keeping volunteer firefighters safe.

Having in mind the necessity of further systematic support for OSP, the Marshal of the Mazovian Voivodeship decided to carry out a comprehensive analysis of their needs by surveying the Mazovian voluntary fire brigades. The Mazovian Office for Regional Planning in Warsaw (MBPR) was commissioned to do this analysis. Among others, the MBPR performs tasks related to regional development on behalf of the voivodeship self-government.

With regard to the statutory obligations of municipal self-governments towards OSP, the Mazovian Office for Regional Planning requested their assistance in distributing the questionnaires. In November 2019, a letter from the Director of the MBPR was sent to 314 commune heads, mayors or town presidents in the Mazovian Voivodeship. It contained a request to distribute the attached questionnaire survey to the chiefs of all OSP units within the territory of a given municipality, these operating within the National Rescue and Firefighting System (KSRG) and one freely selected unit operating outside the aforementioned system. Replies were received from 630 OSP units located in 257 municipalities. They were analyzed in order to identify the main problems and challenges in their functioning.

\section{Role of voluntary fire brigades in the fire protection system and basic principles of their activity and financing}

National Firefighting and Rescue System is an integral part of the national internal security system. Its mission is to protect life, health, property and the environment through forecasting, identifying and fighting fires or other natural disasters, as well as providing technical, chemical, ecological and medical rescue. State Fire Service (PSP) and selected units of voluntary fire brigades (within KSRG) constitute the core of the system. It comprises also other services and entities that cooperate in rescue operations. The Ministry of Internal Affairs is supervising KSRG, whereas the determination of tasks, their coordination and control at national, regional and district levels are the responsibility of the Commander-in-Chief of the State Fire Service, a governor and a starost. Within scope defined by a governor, a head of municipality (mayor, city president) coordinates the functioning of the system in that municipality [article 14 paragraph 5 of the Act on Fire Protection]. When fire protection units, including OSP, want to be included in KSRG, they need to meet the required standards of equipment and training. A declaration of an entity to remain in permanent readiness to undertake rescue actions is also a prerequisite [Regulation ... 2014, (§ 2 sec. 1)]. Many OSP units do not belong to the National Rescue and Firefighting System due to not meeting the requirements.

In the Mazovian Voivodeship, about 2 thousand OSP units are operating in 296 municipalities in total [www.mazovia.pl 07.02.2020], of which 541 are within KSRG [Data from the Headquarters ... 2020]. 
Voluntary fire brigades' operations are regulated by the Act on Fire Protection of 24 August 1991. The OSP units function as associations under the Polish legal system and they are governed by the Act on Associations of 7 April 1989. Their statutes specify tasks and the organisation of the OSP units in detail. However, any arrangements concerning fire protection must be consulted with local Fire Chiefs of the State Fire Service.

In addition to fighting fires, natural disasters and other local threats, the statutory tasks of OSP also include social activities, in particular: organising events that promote sports and physical culture, educational and cultural initiatives promoting fire protection knowledge and skills, as well as supporting cooperation between local social and economic partners in the field of fire protection, and teaching first aid methods among people [Art. 19 par. 1a the Act on Fire Protection].

OSP is financed in two ways. As associations, they obtain funds for the realisation of their statutory goals from membership fees, donations, income from their activities and grants, allocated under rules outlined in separate regulations. The sources of financing their activities as fire protection units come from the Act on Fire Protection [Art. 29 of the Act on Fire Protection] and can be covered from the national budget (participation in costs of maintenance of the OSP units included in KSRG [Art. 33 par. 1 of the Act on Fire Protection]) and from the budgets of local self-governments.

The Mazovian Voivodeship self-government, recognizing the role and importance of Voluntary fire brigades in the system of fire protection and national internal security, for many years has continuously provided financial support to municipalities so that they can fulfil their statutory tasks concerning OSP. The funds granted so far have significantly improved the standards of equipment of the Mazovian units and have increased the level of safety of their members, which in turn allowed many units to be included in the KSRG. More than 3 thousand OSP units have received support from the voivodeship budget in the total amount of approximately 90 million PLN [www.mazowia.pl 07.11.2019] between 2006-2019. New editions of two initiatives have been launched in 2020, aimed at increasing the effectiveness of rescue operations and increasing the standards of work of volunteer firefighters: OSP-2020 - offering co-financing of purchase of new fire-fighting and rescue vehicles, specialist equipment and personal protective clothing for the OSP units and MAZOWIECKIE STRAŻNICE [MAZOVIAN WATCHTOWERS] OSP-2020 - providing financial assistance to cover the costs of renovation works in OSP fire stations. This support covers both the units being within KSRG as well as those that meet the specific requirements or aspire to meet them. In order to fight the epidemic of COVID-19 coronavirus in 2020, the Mazovian Voivodeship self-government provided additional financial assistance for the purchase of protective equipment [www.mazovia.pl 09.04.2020]. 


\section{Analysis of the survey results}

Questions 1-4 of the questionnaire were aimed at obtaining information about the OSP units participating in the survey: their location, number of firefighters and their membership in KSRG. This was used to create a statistical analysis of answers to particular questions.

Questions 5-10 pertain to identifying the problems and needs of OSP. When analysing the results of this section we added up the numbers of similar answers and determined the percentage share of the OSP units reporting a problem/need in relation to the total number of the respondents.

Most of the OSP units participating in the survey are part of KSRG (63\% of the respondents). The analysis of all the responses from all the surveyed OSP showed that the nature of the problems and needs reported by them is similar, regardless of their membership in KSRG. Therefore, all of the surveyed OSP units' answers have been presented for this analysis (without separating them according to their connection to KSRG).

630 OSP units from 257 municipalities provided their answers to the questionnaire survey, of which 400 units were within KSRG (74\% of this type - Fig. 1) and 230 units were functioning outside it. The number of volunteer firefighters who completed the questionnaires varies from 3 to 160 per OSP unit.

The survey exposed a problem of lack of preparation of a great part of the Mazovian OSP units to carry out specialized rescue actions - 182 respondents $(29 \%)$ stated that they are not prepared for it.

A total of $448(71 \%)$ of the surveyed OSP units expressed their preparation to carry out specialized rescue actions to a different extent. Most of the units (over 300) are prepared to carry out technical and road rescue operations, many also declared that they are prepared to conduct medical and firefighting rescue actions (about 150 units each). The respondents also declared readiness to carry out water, height and chemical rescue operations, as well as assist in mitigating the effects of natural disasters - less than 100 respondents indicated having appropriate competencies in each case.

A significant part of the OSP units operating in the Mazovian Voivodeship declared that they needed to improve their equipment (Fig. 2).

Most of the surveyed OSP units - $530(84 \%)$ - indicated the need for investments in fire stations. The most frequently mentioned wishes were: renovation, modernisation or construction of a fire station and installation of central heating. A garage and purchase of equipment for fire stations were also brought up by the survey participants.

Personal protection was the second most common type of response in the area of the necessary equipment. This issue was reported by 524 OSP units (83\%). The need to purchase personal protective clothing, footwear, helmets, gloves, chimney sweeps and breathing apparatuses was frequently emphasised.

Owning a medium or heavy fire-fighting and rescue vehicle by an OSP unit is one of the criteria for inclusion in KSRG. Therefore, it is particularly important for the units included or aspiring to be included in the above-mentioned system. 467 units ( $74 \%$ of the respondents) have stated their needs in terms of acquiring vehicles. OSP requirements assume the purchase 


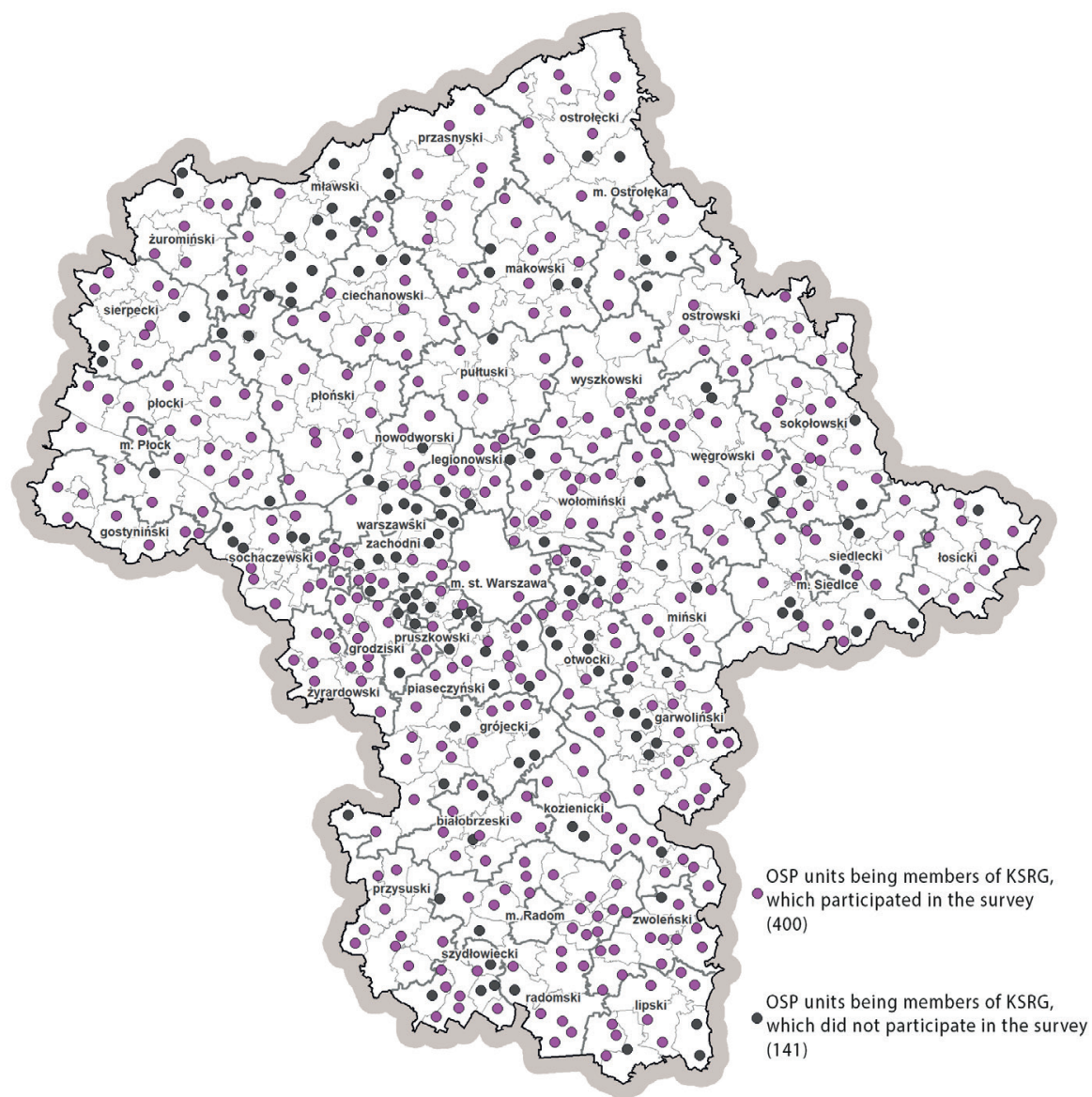

Fig. 1. The participation in the survey of OSP units included in KSRG

Source: MBPR study based on data from the Regional Headquarters of the State Fire Service in Warsaw (as of March 13,2020) and the questionnaire survey

of medium, light and heavy fire-fighting vehicles. Many units requested several types of fire-fighting vehicles. Some of them, mostly from municipalities located on large rivers, expressed the need for vehicles enabling boat transport or off-road vehicles that can be used for water rescue operations.

466 OSP units (74\% of the respondents) reported the need to purchase fire-fighting equipment. According to them, the most necessary equipment includes generators (smoke extractors or power generators), respiratory protection equipment, fire-fighting and water-foam fittings, fire hoses and motor pumps.

Needs related to uniforms were reported by 461 OSP units participating in the survey $(73 \%)$. The most frequent were: purchase of clothing and shoes for barracks use, formal uniforms and protective clothing. 


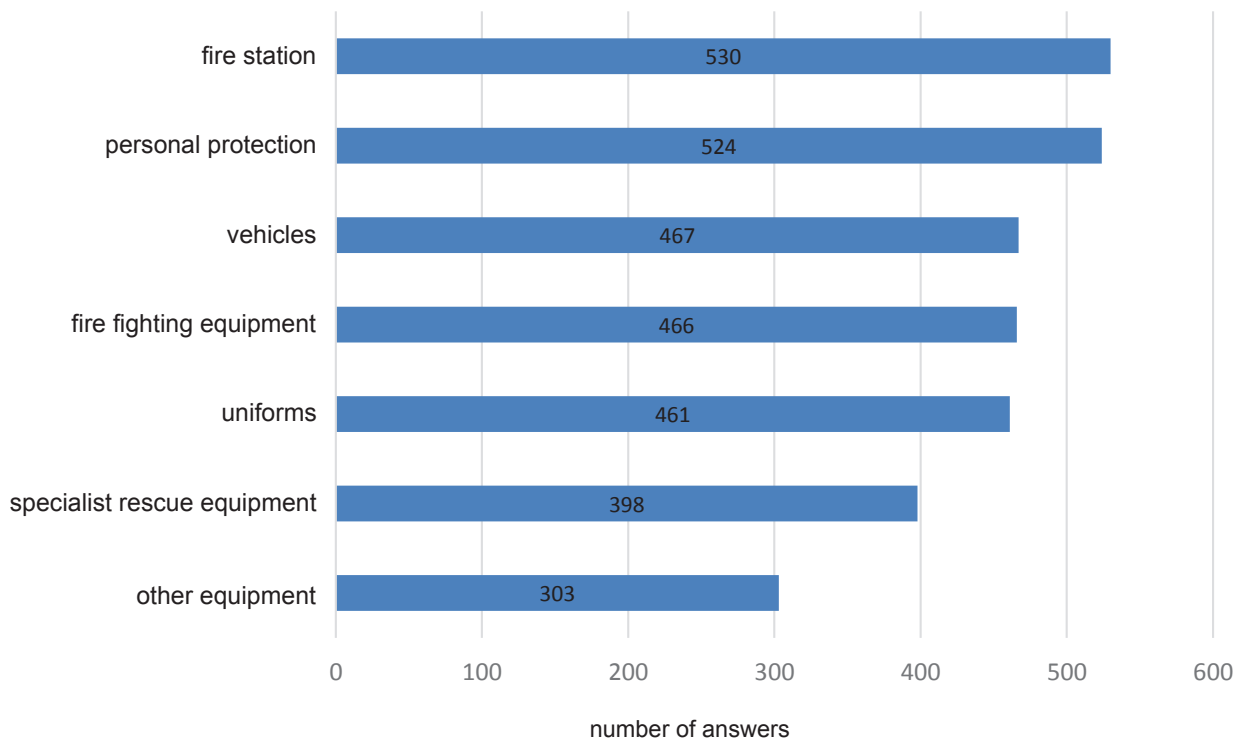

Fig. 2. Equipment needs of the OSP units

Source: MBPR study based on the questionnaire survey

Specialist rescue equipment was requested by 398 respondents $(63 \%)$. The following answers were the most frequently indicated: obtaining a thermal imaging camera, hydraulic tools and equipment for technical, road, water and medical rescue.

In addition, 303 OSP units (48\% of the respondents) reported the need for other equipment, with the most frequent responses being purchasing of: communications equipment (radiotelephones, radio sets, alarm systems), power generators, torches, and washing machines for specialist clothing.

The various needs for increasing the efficiency of OSP members to carry out rescue actions are presented in Figure 3.

Training needs were conveyed by 511 OSP units, i.e. $81 \%$ of the total number of respondents. The most frequently mentioned answers included: receiving training in medical rescue (especially first aid) and basic training for OSP firefighters. Units also declared the need for training in the following areas: technical rescue, water rescue (most often reported by units operating in municipalities located along the Vistula river in the Mazovian Voivodeship) and height rescue.

330 OSP units (52\% of the surveyed) reported a problem with recruiting new volunteer firefighters. The respondents also pointed out a limited number of firefighters who have the possibility to participate in rescue operations carried out during their standard working hours and the insufficient number of qualified people to drive emergency vehicles. In many cases, the problem lies in the availability of volunteer firefighters with adequate training to participate in more difficult actions. This draws attention to the previously mentioned need for additional training.

154 surveyed OSP units (24\%) in the voivodeship indicated the need for making specialist health examinations and medical care available to them. The most frequently reported needs 


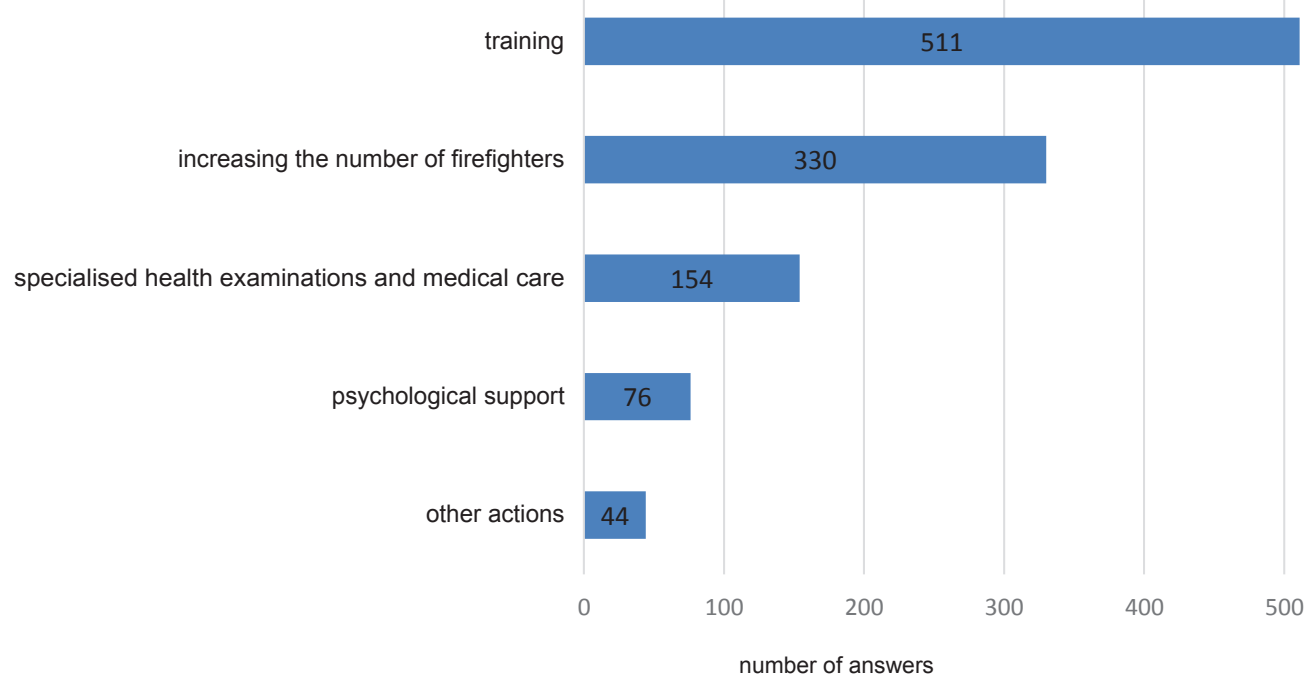

Fig. 3. Needs for increasing the efficiency of OSP members to carry out rescue actions Source: MBPR study based on the questionnaire survey

were: periodic examinations, medical clearance for work at heights, specialist examinations for drivers of emergency vehicles and allergies to insects. Many respondents also asked for quicker access to specialist examinations.

Psychological support for volunteer firefighters was requested by only 76 OSP units participating in the study (12\%). The most frequent responses included: free access to psychological consultations, appointments with a psychologist (periodically or after major rescue and firefighting actions), organisation of stress management meetings.

44 OSP units (7\% of those taking part in the survey), indicated that their members needed to increase their efficiency in carrying out rescue operations in other ways. The most frequently mentioned were: establishing sports facilities, organising field training, reducing bureaucracy and training residents in fire protection methods.

The respondents declared their willingness to carry out a broad range of social activities and to cooperate with other OSP units (Fig. 4).

457 respondents (73\%) declared their willingness to engage in sports activities. Frequent responses included: organisation of fire-fighting and sports competitions (including football and table tennis tournaments), creating or modernising a gym and promoting sport among children and young people.

410 respondents $(65 \%)$ expressed willingness to cooperate with other OSP units in Poland and abroad, which was most frequently seen as a possibility to exchange experience. Other forms of cooperation, such as exercises, training, competitions, cooperation in rescue operations, integration trips and mutual visits, were also pointed out. 


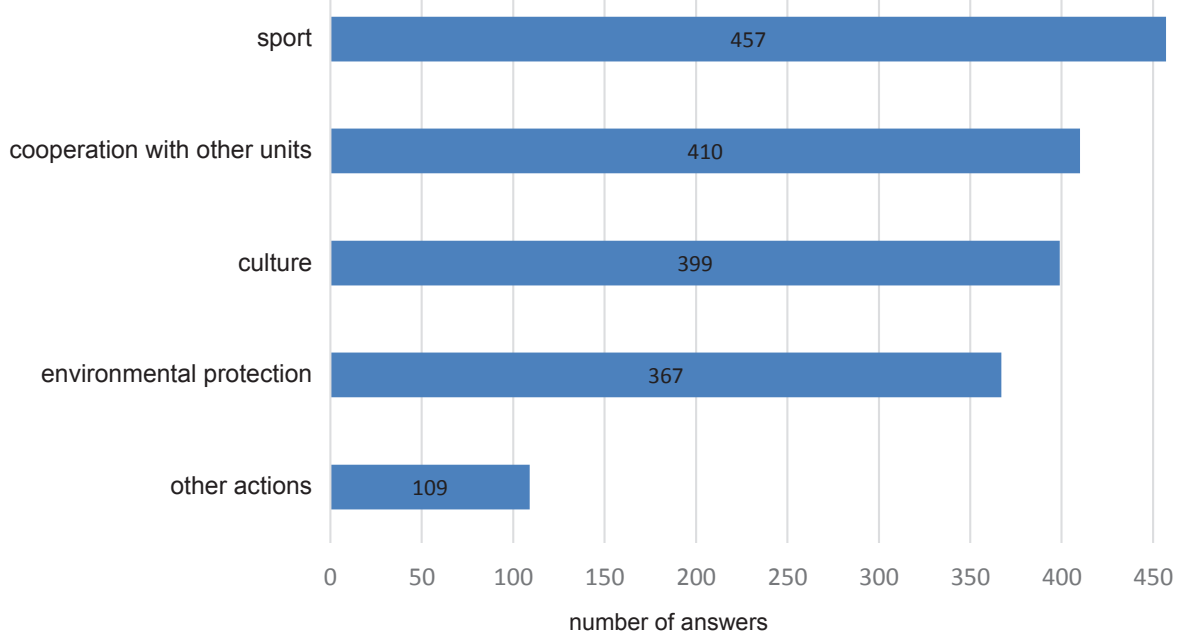

Fig. 4. OSP plans concerning social activity and cooperation with other fire brigades Source: MBPR study based on the questionnaire survey

The intention to conduct or develop cultural activities was reported by 399 of the respondents $(63 \%)$. The responses show that OSP units want to engage in: education of children, young people and residents of a municipality in the field of fire protection, running of firefighters brass bands, participation in the church celebrations and cultural events, organisation of events, shows and various pieces of training. They also expressed readiness to cooperate with local NGOs.

367 OSP units that responded to the questionnaire (58\%) intend to carry out or develop environmental protection initiatives. Their most frequent declarations included participation in "clean up the world" campaigns and promotion of pro-environmental attitudes among local communities, e.g. by organising informative and educational meetings on the harmfulness of burning grass and waste, waste segregation and fire prevention.

109 OSP units participating in the survey $(17 \%)$ wanted to conduct or develop other types of activities. The most common were: organisation of first aid classes for children and young people, promotion of safety and first aid among local communities, cooperation with self-government units and associations, and securing cultural events and celebrations.

Almost all of the OSP units participating in the survey indicated the need for various types of support, especially financial - such an answer was given by 599 respondents (95\%) (Fig. 5).

The units requesting financial support require funds mainly for construction or repair of fire stations, purchase of equipment, uniforms and vehicles as well as for conducting cultural and educational activities.

352 surveyed OSP units (56\%) expect support in the form of regulations promoting the activities of OSP members. Those who see such needs are most often expecting a reduction 


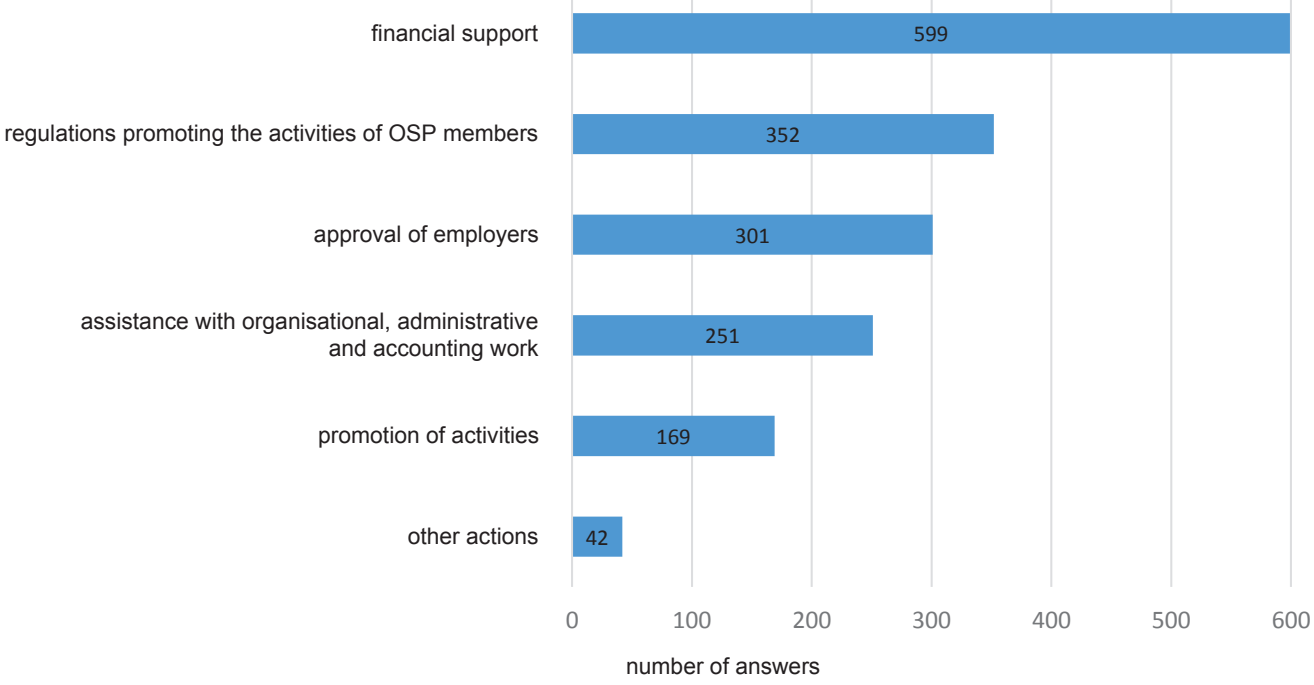

Fig. 5. Needs of OSP units for various forms of support

Source: MBPR study based on the questionnaire survey

in the retirement age or special pension benefits for OSP firefighters. They are also hoping for special benefits for participating in rescue operations and additional deductions and discounts (including tax deductions for employers hiring volunteer firefighters).

The need for the approval of employers towards the activities of volunteer firefighters was declared by 301 OSP units (48\% of the respondents). They expect most often to be granted absence from work during rescue and fire-fighting actions and to be allowed to leave work for fire-fighting training. As the survey shows, there are major problems in this area.

About $40 \%$ of the OSP units participating in the survey (251) declared the need for assistance in organisational, administrative and accounting works. The most frequent response was the need for support in general bookkeeping, including drawing up reports and financial accounts, obtaining and handling grants. The need for training in accounting was also raised.

The need for support in the promotion of activities was declared by 169 respondents $(27 \%)$. The most frequent answers were: organisation of special events and social initiatives, including nationwide actions promoting the idea of voluntary firefighting, seeking sponsors, maintaining a website. As can be seen from the responses, OSP units perceive promotional activities as a tool for attracting new members. Most of those (72\%), who declared they needed support in this area, also voiced their wish to increase the number of volunteer firefighters.

Only 42 respondents (7\%) pointed out the need for support in the form of other activities, e.g. by introducing pension benefits, tax deductions, free legal assistance and legislative changes which would enable OSP to carry out their statutory activities more easily.

An open question - the last one in the questionnaire - allowed respondents to answer freely and identify other unusual problems and challenges faced by OSP units. 164 respond- 
ents $(26 \%)$ when replying to this question most often indicated the problems and needs, which were already mentioned in the previous parts of the questionnaire, e.g. the need for replacing a vehicle, building or renovating a fire station, difficulties in recruiting new members. New issues highlighted by the respondents were: problems related to running firefighter brass bands (difficulties in obtaining funds for the purchase of instruments and lack of volunteers) and limited possibilities of joining KSRG due to owning insufficient equipment. The surveyed OSP units also reported the need to make raising funds for their statutory activities easier and to raise the age limit for participating in firefighting and rescue operations (after obtaining a medical certificate confirming the absence of contraindications).

\section{Summary}

The analysis of the main problems and challenges in the functioning of the Voluntary Fire Brigades in the Mazovian Voivodeship, based on the results of the survey conducted between 2019 and 2020, showed that - despite being provided with systematic support - the OSP units face many obstacles and limitations in their public safety service. The needs for equipping units with specialised equipment and for increasing the efficiency of their members are particularly significant:

- $\quad$ more than $80 \%$ of the OSP units reported shortages in fire station equipment and personal protection, and requested additional training,

- more than $70 \%$ of the respondents declared needs concerning: uniforms, vehicles and fire-fighting equipment,

- more than $60 \%$ of the respondents do not own adequate specialist rescue equipment.

The survey also showed that social activities are an important aspect of OSP undertakings, which also present certain difficulties. A large number of the respondents declared their intention to carry out or develop the following types of activities:

- over $70 \%$ - sports,

- over $60 \%$ - culture and cooperation with other units at home and abroad,

- more than $50 \%$ - environmental protection.

Another very serious problem, identified in the survey, is the challenge of recruiting young people who would be ready to selflessly engage in volunteer firefighting - about $50 \%$ of the respondents declared difficulties in attracting new volunteers. A similar number of the surveyed units expressed expectations regarding changes in the legislation promoting the activities of OSP and declared needs regarding the approval of employers towards the activities of volunteer firefighters.

Due to the fact that the retrofitting of OSP units is an ongoing and financially demanding process, more than $95 \%$ of the units stated the need for further financial support.

The analysis of the results of the questionnaire survey showed a wide range of needs of the Mazovian OSP units, in particular concerning equipment and training aimed at increasing the efficiency of their members. The different situation of various OSP units, affected by many 
factors, such as the financial condition of municipalities or being a member of KSRG, entails the necessity of acquiring external financial resources. These funds are necessary for the efficient functioning of OSP, and thus for ensuring the safety of the region.

\section{Glossary of abbreviations}

KSRG - National Rescue and Firefighting System

MBPR - the Mazovian Office for Regional Planning in Warsaw

OSP - Voluntary fire brigades

PSP - State Fire Service

\section{References}

Barański M., 2018, Obowiazki gminy w zakresie ochrony przeciwpożarowej [in:] Ochotnicze Straże Pożarne Zadania - Samorząd - Bezpieczeństwo, Raport z badań, Uniwersytet Wrocławski, Wrocław, pp. 103-114.

Data from the Provincial Headquarters of the State Fire Service in Warsaw [as of 13.03.2020].

Marjański A., 2017, Rola Ochotniczych Straży Pożarnych w zapewnieniu bezpieczeństwa ludności. Edukacja warunkiem bezpieczeństwa w XXI w. [in:] M. Kopczewski, D. Sienkiewicz (ed.), Bezpieczeństwo publiczne wczoraj $i$ dziś, Centrum Szkolenia Sił Powietrznych im. Romualda Traugutta, Koszalin, pp. 131-147.

Radkowski R., 2015, Krajowy System Ratowniczo-Gaśniczy jako element organizacji ratownictwa i ochrony ludności w Polsce, Zeszyty Naukowe Państwowej Wyższej Szkoły Zawodowej im. Witelona w Legnicy, 14, pp. 37-49.

\section{Documents and legal acts}

Regulation of the Minister of Internal Affairs and Administration of 3 July 2017 on the detailed organisation of the national rescue and firefighting system (Journal of Laws of 2017, item 1319).

Regulation of the Minister of Internal Affairs and Administration of 15 September 2014 on the scope, detailed conditions and procedures of including fire fighting protection units in the national firefighting and rescue system (Journal of Laws of 2014, item 1317).

Act of 24 August 1991 on fire protection (Journal of Laws of 2020, item 961 as amended).

Act of 7 April 1989. Law on Associations (Journal of Laws of 2019, item 713 and of 2020, item 695 and 1086). 


\section{Websites}

https://www.ppoz.pl/ [accessed on 07.02.2020].

https: //www.mazovia.pl/aktualnosci / art,7345, pieniadze-na-ogrodki-dzialkowe-osp-iczyste-powietrze.html [accessed on 13.02.2020].

https://www.mazovia.pl/aktualnosci/art,7678,o-przyszlosci-osp.html [accessed on 07.11.2019].

https: / www.mazovia.pl / aktualnosci / art,7886, samorzad-wojewodztwa-110-mln-zl-naprogramy-wsparcia-dla-mazowszan.html [accessed on 07.02.2020].

https: //www.mazovia.pl / aktualnosci / art,7986,8-mln-zl-na-srodki-ochrony-dlamazowieckich-osp.htlm [accessed on 09.04.2020]. 


\section{Analiza głównych problemów i wyzwań w działalności ochotniczych straży pożarnych w województwie mazowieckim}

\section{STRESZCZENIE}

W artykule zaprezentowano wyniki analizy głównych potrzeb, problemów i wyzwań związanych $\mathrm{z}$ działalnością ochotniczych straży pożarnych z terenu województwa mazowieckiego. W celu ich identyfikacji przeprowadzono badanie ankietowe, skierowane do mazowieckich jednostek OSP. Przedmiotowa analiza pozwoliła m.in. na rozpoznanie potrzeb ochotniczych straży pożarnych w zakresie poprawy wyposażenia, podnoszenia sprawności członków jednostek do prowadzenia akcji ratowniczych oraz zebranie informacji na temat przygotowania jednostek do prowadzenia działań ratowniczych. Nadesłane odpowiedzi umożliwiły także ustalenie najbardziej pożądanych przez jednostki OSP form wsparcia ich działalności.

Niniejszą analizę uzupełniono również o podstawowe informacje nt. Krajowego Systemu Ratowniczo-Gaśniczego i analizę przepisów będących podstawą działalności i finansowania ochotniczych straży pożarnych, w tym w szczególności ustawy z dnia 24 sierpnia 1991 r. o ochronie przeciwpożarowej i ustawy z dnia 7 kwietnia 1989 r. Prawo o stowarzyszeniach.

Słowa kluczowe: ochotnicze straże pożarne, Krajowy System Ratowniczo-Gaśniczy, województwo mazowieckie

Paulina Żurawicka - a graduate of Warsaw University of Life Sciences in the field of spatial management, regional government employee, contact: Mazovian Office for Regional Planning in Warsaw, Branch office in Siedlce, ul. Pułaskiego 19/21, 08-110 Siedlce, e-mail:pzurawicka@mbpr.pl

Paulina Żurawicka - absolwentka gospodarki przestrzennej Szkoły Głównej Gospodarstwa Wiejskiego w Warszawie, pracownik samorzq̨dowy, kontakt: Mazowieckie Biuro Planowania Regionalnego w Warszawie, Oddział Terenowy w Siedlcach, ul. Pułaskiego 19/21,08-110 Siedlce, e-mail: pzurawicka@mbpr.pl

Monika Kierzkowska - graduate of the Academy of Podlasie in Siedlce (currently: the University of Natural Sciences and Humanities), postgraduate of the Cardinal Stefan Wyszyński University in Warsaw in the field of the Structural Funds of the European Union, regional government employee, contact:Mazovian Office for Regional Planning in Warsaw, Branch office in Siedlce, ul. Pułaskiego 19/21, 08-110 Siedlce, e-mail:mkierzkowska@mbpr.pl

Monika Kierzkowska - absolwentka Akademii Podlaskiej (obecnie Uniwersytet Przyrodniczo-Humanistyczny) w Siedlcach, studia podyplomowe w zakresie Funduszy Strukturalnych Unii Europejskiej na Uniwersytecie Kardynała Stefana Wyszyńskiego w Warszawie, pracownik samorzq̨dowy, kontakt: Mazowieckie Biuro Planowania Regionalnego w Warszawie, Oddział Terenowy w Siedlcach, ul. Pułaskiego 19/21, 08-110 Siedlce, e-mail:mkierzkowska@mbpr.pl

Dariusz Piwowarczyk - graduate of the University of Warmia and Mazury in Olsztyn in the field of spatial management, postgraduate of the Gdańsk University of Technology in the field of architectural and urban renewal of urban areas, regional government employee, contact: Mazovian Office for Regional Planning in Warsaw, Branch office in Siedlce, ul. Pułaskiego 19/21, 08-110 Siedlce, e-mail:dpiwowowarczyk@mbpr.pl

Dariusz Piwowarczyk - absolwent gospodarki przestrzennej Uniwersytetu Warmińsko-Mazurskiego w Olsztynie, studia podyplomowe w zakresie rewitalizacji architektoniczno-urbanistycznej obszarów miejskich na Politechnice Gdańskiej, pracownik samorzqdowy, kontakt: Mazowieckie Biuro Planowania Regionalnego w Warszawie, Oddział Terenowy w Siedlcach, ul. Pułaskiego 19/21, 08-110 Siedlce, e-mail:dpiwowaczyk@mbpr.pl 